\title{
Traditional And Virtual Performance Management Functions In The Age Of Information Technology
}

Bahaudin Mujtaba, (Email: mujtaba@nova.edu), Nova Southeastern University Donovan A. McFarlane, (Email: Donovan@nova.edu), Nova Southeastern University

\begin{abstract}
The effects of information technology developments on the traditional roles of managers over the past decades have been extraordinary, especially when we consider the numerous changes these developments have brought to the global environment of business. The paper examines these effects by examining the changing nature of managerial roles in historical and contemporary contexts. The paper briefly describes managerial roles and functions dating back to the Industrial Revolution and Scientific Management era, with transitions up to the present technological and service-oriented market economies in which the use of information technology (IT) and knowledge have become vital tools for survival, growth, the building of competitive advantage, and success in achieving organizational goals. The paper examines the effects of information technology (IT) developments on the role of managers using the four fundamental functions of management theory: planning, organizing, controlling, and leading. The paper concludes with an examination of information technology developments on the roles of managers from a Mintzbergian viewpoint.
\end{abstract}

\section{INTRODUCTION}

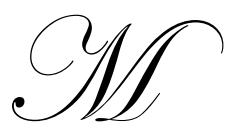

anagerial roles in contemporary organizations have radically shifted due to global competition, advances in new information technologies (IT), and rapid developments in e-commerce and ebusiness transformations. The changes resulting from the simultaneous developments in information technology and the globally competitive marketplace have significantly affected managerial tasks, functions, and responsibilities. This is particularly well-reflected in the scope of managerial roles spanning virtual business environments where concepts such as the digital firm and other emerging technologically-derived business jargons effectively describe the nature and process of contemporary business as affected by the factors identified above. These factors along with the changing attitudes towards business processes and the need to swiftly adapt to global requirements and standards have transformed managerial roles from their simple traditional context into more highly conceptualized definitions. As a result, managers must now effectively blend their styles of management into an allencompassing and integrative approach, where IT considerations and strategies are geared towards achieving organizational goals (Mujtaba and McFarlane, 2005).

The information technology competence of managers has in recent years become very important in defining organizational success and performance (Bassellier, et al, 2001). Managers have become more knowledgeable in the use and applications of IT principles and strategies, recognizing how technology has transformed their roles from the simple traditional functional approach to ones where effectively utilizing an integrated approach to leading, planning, controlling, and organizing becomes the norm. Effectively utilizing IT can greatly enhance employee and organizational productivity, and will result in increased business performance as businesses strive to gain a competitive edge in the new economy. Utilizing IT in performance management will allow business firms to continuously assess and improve employee and corporate performance as measured against clearly defined goals, standards, and targets. IT has tremendously affected performance management approach and practices with regards to non-comparable data, the volatility of the global environment, the effect of distance and level of subsidiary maturity in developing economies (Mujtaba and McFarlane, 2005). Furthermore, IT has also had its impact on performance from 
the point of view of monitoring and control systems domestically and globally. With this importance attached to IT in the transformation and transition of managerial roles and functions, contemporary business managers must possess a unique set of IT-related explicit and tacit knowledge which will enable them to successfully exhibit IT leadership in business (Bassellier, Reich and Benbasat, 2001, p. 159).

To successfully guide workers in the new global economy to achieve organizational goals and develop competitive gains, managers must view themselves as IT managers, since their tasks essentially revolve around the use and application of IT systems to effectively coordinate human and capital resources (Mujtaba and McFarlane, 2005). Becoming successful IT managers will require innovative, technical, conceptual and broad-based organizational human skills, as well as a complete understanding of the global environment where networks and virtual opportunities and threats are affecting strategies at all levels. The combination of these skills refers to the Explicit IT Knowledge a managers should possess. According to Bassellier, et al (2001) Explicit IT Knowledge refers to a manager's knowledge of technologies, applications, systems development, and management of IT. As such there are four important information and communications technology systems and tools relevant to managerial roles from a modern IT perspective: supply chain management systems, customer relationship management systems, enterprise systems, and knowledge management systems (Laudon and Laudon, 2004). What managers are essentially entrusted with in today's globally-oriented organizations therefore is effective IT management as information and communications technology systems become the tools for planning, organizing, leading, and controlling the entire organization along with its people and relationships with competitors and business partners.

\section{The Industrial Revolution and Scientific Management}

Management science has undergone dramatic transformations spanning several developmental decades, and these became extremely pronounced after the second hundred years of the Industrial Revolution (Dilworth, 1989, p.45). The first important technological movement to affect the science of management and the roles of managers was the Industrial Revolution, followed by the Scientific Management Era, which brought profound developments to many organizations in Europe and the rest of the world. The Industrial Revolution and the changes which followed in operations systems and task-orientation led to increased focus on workers, systems, as well as systems thinking and theory. These new thoughts and approaches to management led to more complex definitions of managerial roles, tasks and responsibilities. As a result, managerial roles became the central point of reference when dealing with organizational effectiveness, goal accomplishments, and success.

The Industrial Revolution which was characterized by a shift of the production process to large factories, brought about the need for new management skills as the role of the manager shifted from the supervisory level with majority of time devoted to worker control, along with several new duties and responsibilities (Mujtaba and McFarlane, 2005). With this shift of the production process to large factories, specialization of labor brought about new requirements for management as coordination became a very crucial and more difficult task (Dilworth, 1989, p. 45). The Industrial Revolution and its impact on productive processes and society were not the only factors affecting managerial roles. There were other important social and political revolutions that played their parts in bringing about the transitions in management which have continued into the current century.

\section{The IT Revolution}

With the birth of the computer and the subsequent Information Technology Revolution, the science of management and the role of managers could not remain entrenched in their traditional contexts. Using new tools and methodologies in planning, organizing, leading, and controlling effectuated new schools and modes of thoughts, as well as embellished new practices, standards, and definitions regarding management functions and responsibilities, organizations and their management teams began finding new ways of creating and adding value to gain competitive edge. Information and computer technologies are the most pervasive factors affecting the changing roles and functions of managers and management, and Jones and George (2003) concur with this as they state that new information technologies are having profound effects on the way an organization operates. Jones and George further argue that at the level of organizational structure, IT is changing methods of organizing (p. 292). Managers' roles in today's business organizations have dramatically changed to encompass technology integration along all lines of 
duties and responsibilities. As such, the concept of "technology" has come to define a functional area of management within organizations. This concept of technology refers to the combination of skills, knowledge, tools, machines, computers, and equipment that are used in design, production, and distribution of goods and services (Jones and George, 2003, p.290). The roles of managers have become very complex as knowledge management becomes the major definitional and descriptive terminology ascribed to what were simply called managerial functions or skills (Mujtaba and McFarlane, 2005).

According to Yeh, (2005) knowledge management is the practice of harnessing and exploiting intellectual capital in order to gain competitive advantage and customer commitment through efficiency, innovation, and effective decision making. Managers must manage knowledge in the form of information, communicating across networks and organizational boundaries. Thus, knowledge management entails utilization of "a systematic process that helps organizations identify, select, organize, disseminate, and transfer important information and expertise" (Turban and Aronson, p. 347) internally and externally between cooperative teams, businesses and enterprise networks in achieving organizational goals. The use of IT for managing organizational knowledge; resources; information systems and strategic business plans has transformed the role of the manager into a highly technical and conceptual framework, where interaction is virtual in its approach and application though organizing, planning, controlling, and leading have remained as the fundamental bases of managerial roles (Mujtaba and McFarlane, 2005). These managerial functions are carried out through and within various information technology mediums which today characterize activities, operations and functions within business organizations. Managerial tasks essentially involve effectively and efficiently utilizing information technology in all its forms to plan, organize, lead, and control workers and activities within the organization. Information technology developments have resulted in a need for managers to engage in technology management as a major part of their organizing, planning, leading, and controlling roles. Technology management requires managers to share and integrate expertise within and between functions and divisions through real-time interconnected information technology (Jones and George, 2003, p.292). Knowledge is the major driving force in our new economy (Yeh, 2005) and thus, the role of IT in managerial duties and functions has significantly increased along all lines of business activities. Yeh (2005) further contends that as a new economy resource of tremendous importance, knowledge powers the ability of professionals to be their best and to deliver value service to customers. This delivery of value-services requires managers to impart knowledge of information systems to their employees, incorporating IT into all productive and value-added processes along organizational cultural lines.

Understanding and effectively utilizing knowledge management systems is very vital to managers in their newly defined roles. Allee (1997) defines a knowledge management system as the framework of an integration of elements in organizational culture, organizational information technology infrastructure, along with the organization's store of individual and collective experiences, values, learning and insights, etc. In the global economy and market of the $21^{\text {st }}$ century, managers coordinate these factors through IT available systems using specific knowledge management activities to guide the organization and its members through strategic planning, organizing, controlling, leading, and integration of knowledge resources in arriving at organizational outcomes (Nonaka \& Takeuchi 2001).

Today's managers must use IT to plan, control, lead, and organize resources of various kind from a knowledge-based or information-led orientation, within the context of a learning organization (Mellander, 2001). Therefore, knowledge dissemination and responsiveness become essential factors in achieving competitive advantage as managers use IT strategies to organize resources, control processes, plan for change and lead employees to effectively achieve an organization's goals (Yeh, 2005; Oxbrow, 2000; and McEvily, Das \& McCabe, 2000).

Recent information technology developments have called for effective managers with higher technical, conceptual, and human skills across all organizational boundaries (Robbins and Coulter, 2003). IT affects organizational structures, as well as the nature and skill requirements of jobs and task reporting relationships among electronically connected people, and therefore promotes superior communication and coordination (Jones and George, 2003 , p. 292). Hence, managers are no longer simply viewed as organizational business managers but as business information technology managers. This requires managers to spend more time and attention embracing their informational roles as monitors, disseminators, and spokespersons for organizational change, problem solving strategies, transition of business processes and activities, along with their responsibilities to effectively communicate business needs to employees (Williams, 2000). Today's managers must plan, organize, lead, and control across 
technology systems, managing and handling a wide range of problems and people on a regular basis. Because many organizations are now global businesses, these problems and people are often remote and require managers to be engaged in virtual planning, organizing, leading, and controlling. Management has become a virtually oriented and technology-based challenge for managers. The role of contemporary managers essentially involves the elements of complexity, technologically-based systems and tools, speed, and the application of strategies and standards across virtual organizational designs. In essence, managers are now virtual and global IT managers (Mujtaba and McFarlane, 2005).

\section{MANAGERIAL ROLES IN THE CONTEXTS OF E-COMMERCE AND THE EMERGING DIGITAL FIRM}

The vast developments in information technology have given rise to increased activities on the internet via ecommerce and strategic networking. The role of managers have therefore changed as their duties and responsibilities include e-commerce, network, database and systems management, while maintaining control over time, people, and other resources. Managers must now engage in a variety of different functions which require greater digital skills and abilities as they plan, control, lead, and organize through virtual networks linked across organizational and systems boundaries (Mujtaba and McFarlane, 2005).

Managers must now view management from an information technology perspective as they strive to achieve effectiveness and efficiency through planning, organizing, leading, and controlling organizational resources and market factors to achieve business goals using IT systems and strategies. IT systems and strategies are now at the center of management roles, responsibilities, and functions.

IT is at the heart of management's functions in the new economy where having sound information and technology systems knowledge allows organizations to develop and deliver new and innovative value services to their customers. Performance management is a function of being both effective and efficient. Therefore, performance management requires both leadership and management skills. The relationship between effectiveness, the four traditional functions of management, and efficiency is graphically visualized (Mujtaba and McFarlane) as demonstrated in Figure 1. Managers coordinate these functions using IT systems and strategies to achieve organizational goals.

Figure 1: Performance Management Model

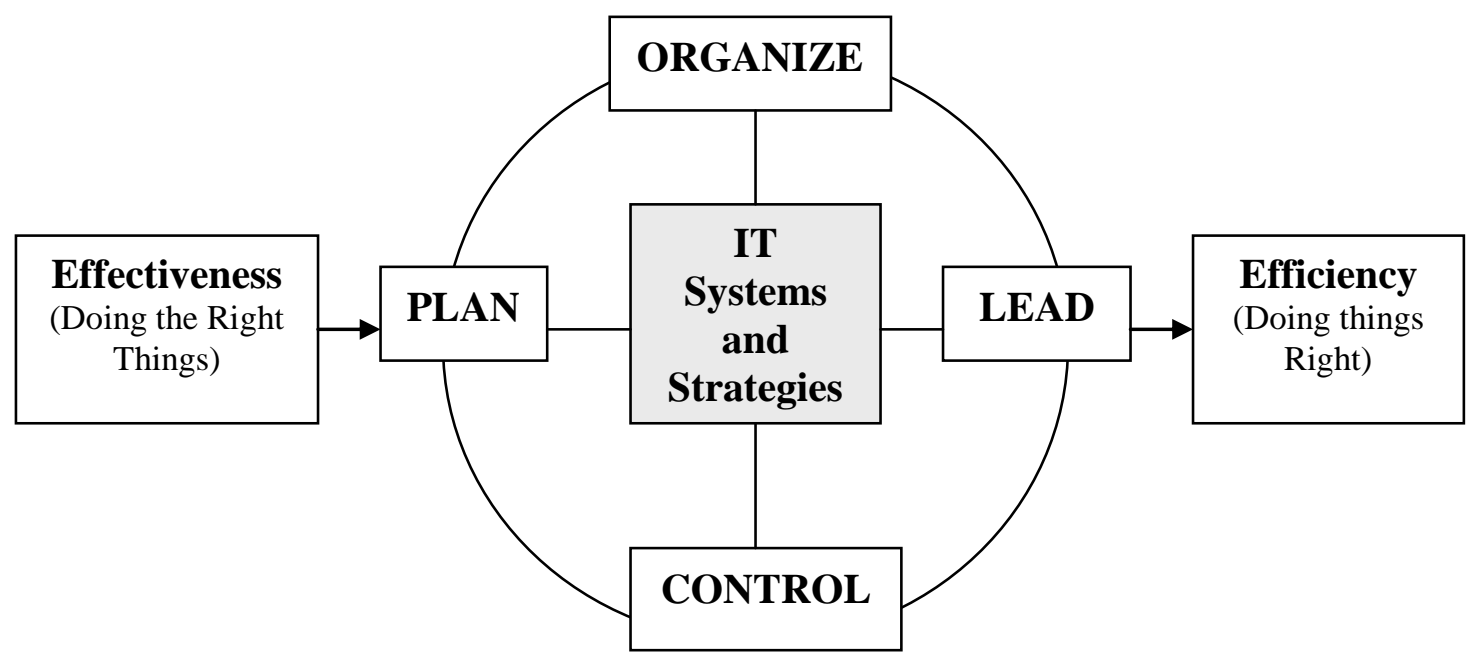


An important development characterizing the volatile global market environment in which managers carry out their roles today is the emergence of the digital firm. The concept is described by Laudon and Laudon (2004) in reference to businesses in which nearly all of an organization's significant business relationships with customers, suppliers, and employees are digitally enabled and mediated. This digital firm envisioned holds powerful implications as to the changing roles of managers in a uniquely modern IT environment characterized by change and uncertainty. The digital firm is based on sound technology platforms and managers in such firms will have to possess superior IT knowledge to use information and communications technology systems to plan, control, lead, and organize business processes, activities and people. Essentially, these managers become involved in IT resource management, since every resource within a firm becomes an extension of the IT function.

Information technology in today's competitive environment is the most significant factor which organizational managers can utilize to level the playing ground and survive in the global market. Managers must use IT to coordinate the resources which will result in effectiveness and efficiency at all levels when making decisions, developing action plans and resolving organizational conflicts and problems. According to Laudon and Laudon (2004) "a substantial part of management responsibility is creative work driven by new knowledge and information" (p. 14). Knowledge and information have become the twin-drivers of value in the new economy, and Laudon and Laudon argue that "each level of management has different information needs and information systems requirements" (p. 14). Therefore, IT spans the entire management spectrum and must likewise flow to all levels of the organization.

The environment in which managerial roles and responsibilities are carried out today is characterized by unpredictability and rapid changes in information and communications technology, high levels of competition, and increasing marketspace. Managers are therefore preoccupied with planning, organizing, leading and controlling organizational resources with the element of change transforming business processes, success and activities. Today's managers must strategically plan for and change within various contexts in order to achieve organizational goals. According to Laudon and Laudon, (2004), "Information technology is one of many tools managers use to cope with change." (p.14). Using IT infrastructure managers in organizations are able to accomplish goals and perform tasks through applying available technology services effectively. IT infrastructure simply describes the physical arrangement of hardware, software, databases, networks, etc. (Turban, McLean and Wetherbe, 1996).

E-commerce, which refers to the "the process of buying and selling goods and services electronically involving transactions using the Internet, networks, and other digital technologies" (Laudon \& Laudon, 2004; p. 2324), has taken over the way business is conducted in $21^{\text {st }}$ century economies. Managers must effectively use IT to develop e-managerial skills and strategies as they plan, organize, lead and control within the context of electronic trade and the structural and business relationships which are involved in virtual operations and transactions. Effectively managing in such an environment requires managers to carry out their duties and responsibilities "using information flows in new and dynamic ways" (p. 24) such as coordinating resources and monitoring their interaction (both information and human resources) to create and deliver value to customers globally.

Because the functions of planning, controlling, organizing, and leading are at the heart of management thoughts and theories, they remain fundamental in defining and describing managerial roles, duties and responsibilities. The transitions that have taken place in managerial roles represent changes within the functions as managers adapt and respond to processes such as globalization, industrialization, digitalization, e-commercialization, enterprise and organizational convergence and transformations concordant with contemporary technological and socio-economic developments.

\section{THE IMPACT OF STRATEGIC IT FRAMEWORKS}

Contemporary managerial roles encompass the management of IT systems, as well as effective management of a business organization's physical and human resources through the use and application of IT to business challenges and problems. Achieving targeted objectives including profits, productivity, success and growth requires the efficient and effective use of IT systems. Turban, McLean and Wetherbe (1996) believe that information systems help businesses to increase sales, reduce costs by lowering inventory, increase quality of products, create alliances 
with suppliers, reduce costs by negotiating high quality at low prices, reduce costs by optimizing the use of shelf space, increase productivity, and concentrate on core business units and assets.

One of the most important aspects of changing managerial roles resulting from increased use of IT is the recognition and implementation of strategies to effectively integrate IT into daily business functions and processes. In today's information and knowledge driven environment IT must become the tool through which the manager accomplishes all tasks as he or she plans, organizes, leads, and controls the various input resources into the value creation process. As such, IT has resulted in the managers' roles and responsibilities being transformed into an allencompassing systemic approach to achieving organizational goals as he or she is compelled to add systems, networks, databases, procedures, hardware, and software to the traditional management of people resources (Mujtaba and McFarlane, 2005).

In performing managerial roles and responsibilities managers as organizational leaders of the $21^{\text {st }}$ century must recognize the indispensable role IT and other technology systems play in accomplishing tasks at all levels of the organization. Moreover, they must recognize the interdependence that has emerged, or rather the synergy between IT and other resource factors in the value process. In order to arrive at this, managers and their organizations should become actively involved in the development and management of IT frameworks such as the value chain and competitive forces models. This IT framework describes the structuring of strategic information systems (SIS) in order to make possible a more plausible understanding and classification of the relationship among strategic management, competitive strategy, and information technology (Turban et al, 1996). When managers become armed with such knowledge they are far more capable than their industry counterparts in conceptualizing and planning for changes, controlling internal and external environmental "controllable factors" impacting business success and performance, leading their companies to the front of the competition, and organizing work teams and resources in what are essentially becoming virtual-boundary-less organizations (Mujtaba and McFarlane, 2005).

Strategic IT frameworks are fundamental to managerial decisions as they effectively integrate systems, tasks and functions to reflect more cohesiveness in organizational task-related performance and productivity output. The development and use of IT as a strategic business or value driver to achieve high productivity is a challenge for managers who are unable to view the entire business organization as a system of tasks, processes and people from a purely technological perspective. Managers in today's business world must take advantage of IT as a strategic driver of people, systems and resources, recognizing that IT is the value driver in the new economy where globalization and the transformation of enterprise are in full swing.

\section{Planning}

Planning is the process of defining organizational objectives and then articulating strategies, tactics, and operations necessary to achieving these goals (Holt, 1990). It is one of the four fundamental areas under which the role of managers can be examined from multiple perspectives; that is, involving different schools of thoughts, as well as the current role of managers as deliberated by IT systems and their applications and uses in business. The process of planning entails deciding which goals the organization will pursue; deciding what course of action to adopt to attain these goals, and deciding how to allocate organizational resources to attain these goals (Jones and George, 2003, p.8). Fortunate for today's managers, they have a variety of tools and systems which are designed to facilitate effective and efficient planning. The information technology systems managers have available to them today make planning a much easier task than their predecessors. There are systems and processes in place to facilitate decision making at the planning level and these range from decision support systems to computer programming, mathematical and materials requirement planning systems (Mujtaba and McFarlane, 2005). Managers of $21^{\text {st }}$ century business organizations are able to carry out their planning role using a variety of conceptual and technical skills to comprehend systems and processes based on input-output measures and standards. Managers are now able to input data into systems and run configuration processes and tasks to determine decisional outlay using such systems as the MRP system (Material Requirements Planning), which is a computer-based method for managing materials required to carry out a production schedule (Dilworth, 1989, p. 150). The MRP system is also called a rough-cut capacity planning system or resource requirement planning system. It helps a manager to determine how much capacity is available and how this capacity will be allocated for production, and how it helps managers develop detailed specific models of what products to 
produce and when. Through the use of information technology managers are able to develop master schedule, or master production schedules, to facilitate efficient and effective planning. Computer systems are used to develop flowcharts of production and capacity planning processes, graphical load reports or load profiles. Furthermore, with aggregate planning systems managers are able to reduce the time spent in the planning process, while maximizing the use of resources including time, people, capital equipment, and the resulting operational costs (Mujtaba and McFarlane, 2005).

Managers have emerged to become organization-wide planners engaged in several activities across the board, and this is the direct result of developments in information technology allowing managers to plan activities at interdepartmental levels and effectively accomplish the cooperative pooling of resources. Communication across departments is facilitated through networking and sharing of information which are vital to achieving production targets and other organizational goals. Several information technology developments and tools such as teleconferencing, email and video-conferencing have aided the planning process by allowing managers to engage in virtual planning across parallel and unparallel organizational boundaries. The result of successful planning is strategy (Jain, 1977; Thompson, Jr., Strickland III \& Gamble, 2005), and the recent developments in information technology have facilitated strategy development, selection and formulation, as well as its implementation and overall success in achieving organizational goals.

Contemporary managers have at their disposal computer simulation programs and games which aid in the planning process. As such, managers do not have to rely on rigorous hours of conceptualization and revisions in planning organizational goals and allocating resources. In most of today's technological organizations there are integrated software packages and production scheduling systems available on information networks to provide immediate feedback to managers. One of the important information technology developments includes advanced linear programming systems for aggregate planning (Dilworth, 1989, p. 163). Today's managers are able to effectively use mathematical formula and concepts for gauging their decisions and arriving at cost-effective production targets with tremendous accuracy success. The result of this has been greater efficiency in operations and the development of competitive advantage for many organizations. Linear programming, which uses Linear Decision Rule (LDR), as well as numerous other methods have become part of the conceptual skills requirements for today's managers in carrying out their roles in the global business market (Dilworth, 1989, p. 164). Overall, the planning role of managers has become less time consuming, but more complex and sophisticated information technology development and changes which managers must quickly adapt. Though managers spend less time planning they have more tasks, are in need of greater technical and conceptual skills, and must be able to view planning from an organizational wide-approach, considering global competition and rapid changes as the most detrimental factors to successful planning.

\section{Organizing}

The manager's role as an organizer involves the grouping and assignment of tasks, as well as the allocation of resources to organizational-specific functional departments in order to effectively accomplish goals. Organizing is the management process of determining how best to arrange an organization's resources and activities into a coherent structure (Griffin \& Ebert, 2004). In their roles as organizers managers are able to establish structural frameworks and interactive working relationships that allow organizational members to cooperate in enacting strategic plans. IT developments have significantly affected the organizational role of managers as IT systems provide them with communicative tools for business networking. Organizing teams and tasks is easily facilitated by IT and communications tools such as teleconferencing, videoconferencing, emails, instant messengers, and other devices which reduce time spent in meetings and face to face communications (Mujtaba and McFarlane, 2005).

Using virtual commands and instructions given over local and wide area networks today's technological managers are able to organize work teams as well as activities of financing, production and marketing with greater accuracy. The effects of IT on the organizing role or function of managers is also evident in the advantage today's managers have in utilizing work space and plant capacity more efficiently using systems configurations tools and equipments to determine production outlays and departmental boundaries. Furthermore, the development of computer visuals and synergistic systems, allow managers to make better organizing decisions as they place workers into interfunctional teams based on information retrieved and stored in computer systems. These systems along with 
production scheduling and other database management decisions allow managers to set production schedule and organize a time frame around which to plan activities, employee training and resources allocation (Mujtaba and McFarlane, 2005).

Managers are now able to analyze and develop, as well as select from several solutions in dealing with problems arising in the daily operation of business. IT facilitates greater task analyzability, which is the degree to which programmed solutions are available to solve the problems encountered by managers in playing their roles (Jones and George, 2003, p. 291). Managers can readily access information when addressing issues of production, labor, and resources shortage or oversupply can use statistical and plant layout information to determine how to organize production in functional departments. Today's managers are less likely than their predecessors to make errors in production, cost and scheduling mistakes that will affect company profits because IT systems and processes facilitate better decision-making when it comes to choosing amongst alternative modes of production such as smallbatch, mass-production or continuous process (Jones and George, 2003, p. 293). Contemporary managers are better able to organize jobs and employees according to task identity, task significance, skill variety and autonomy, while using IT systems to record and ascertain feedback.

Organizing for today's managers is a complex process due to the current nature and processes involved in business activities and transactions via virtual marketspace. However, information technology tools have allowed for more accurate information and less time spent on classifying and gathering relevant data and managers are now able to organize work teams through electronic media. As a result of current available IT tools and systems the organization of production tasks, department structure, product and market structures are now a matter of pushing the right buttons and inputting correct data into electronic database systems designed to configure models based on product or service categories.

Companies in the $21^{\text {st }}$ century are concentrating heavily on teamwork to accomplish organizational goals and having the most up-to-date IT systems will be vital in achieving such objectives. Managers must effectively utilize information technology systems and tools to organize departments according to functions and importance within organizations. Activities and operations relevant to delivering superior value and increasing quality, and overall efficiency and effectiveness in resources allocation, costs and sound management must be organized around technology information systems which link departments, networks and businesses (Mujtaba and McFarlane, 2005).

\section{Controlling}

Managers have a role to evaluate how well the organization and particularly its workers are achieving set goals and objectives, and must take action to maintain or improve performance where necessary (Nickels, McHugh, \& McHugh, 1999). This specifically requires managers to control all organizational resources or production inputs effectively. In order to achieve this managers perform several tasks including monitoring the performance of individuals, departments, and that of the entire organization to determine whether or not desired performance standards are being met. This refers to the controlling role or functions of managers. The monitoring and evaluation of organizational resources requires great efforts and recent information technology developments have aided managers significantly in this role. Managers now have a variety of IT systems to enable effective control, and these are especially vital in the virtual business organization. IT has provided contemporary managers with effective control systems. According to Jones and George (2003), control systems refers to the formal target-setting, monitoring, evaluation, and feedback systems that provide managers with information about how well the organization's strategy and structure are working.

Effective control systems alert managers when something is going wrong, giving them time to respond to opportunities and threats within the organizational environment. Managers in the past did not have such systems and were caught unprepared and had to wait until organizational problems arrived to deal with them. Contemporary managers are able to respond to unexpected events because effective control systems give them greater flexibility and choices. Modern control systems provide managers with relevant and specific information, thereby giving them more accurate pictures of organizational performance. One spectacular advantage that today's managers have been afforded is that of obtaining information from computerized information control systems in a timely manner. This accounts for 
less errors and failure, as well as for better decision making and business success when compared to their predecessors (Jones and George, 2003).

Information and knowledge are two of the most powerful factors affecting the changing roles of managers, and according to Laudon and Laudon (2004), new forms of IT have revolutionized control systems by facilitating the flow of accurate and timely information up and down the organizational hierarchy and between functions and divisions. Today's managers are judged successful and effective through their abilities to utilize IT to channel information and knowledge into those areas that will reap organizational benefits in terms of goal accomplishment, profitability and competitive advantage. The use of computerized control systems has led to greater efficiency in costs and more effective utilization of resources as today's managers spend less personal time controlling systems and people using real time evaluation and monitoring systems throughout the organization. As a result of the development of control and information systems to measure performance at each stage of transforming inputs into finished goods and services (Jones and George, 2003. p. 333), managers are now able to use feed-forward control to anticipate problems before they arise at the input stage of production. This further allows managers to control the quality of the input received from suppliers, as well as labor inputs, time, and other resources which affect the production process. In addition, Turban, McLean, and Wetherbe (1996), believe that IT can also be used to keep in contact with suppliers and manage their progress.

Jones and George (2003) believe that the general development of management information systems provide feed-forward information that provide managers with timely information concerning changes both in the task and general environments of the business. This allows managers greater control over organizational resources, and they become better able to diagnose and respond to business opportunities and threats. IT has also provided the modern manager with concurrent control systems and feedback control systems. A concurrent control system is used at the conversion stage to give managers immediate feedback on how efficiently inputs are being transformed into outputs so that managers can correct problems as they arise (Jones and George, 2003). In so doing concurrent control systems alert managers to respond quickly to whatever is the source of problem, whether it be defective batch of inputs, machines out of alignment, or workers lacking the skills necessary to perform a task efficiently. This system also enables total quality management throughout production and operation systems. Feedback control system using IT on the other hand gives managers information about customers' reactions to goods and services so that corrective action can be taken if necessary. This occurs at the output stage and alerts managers about the number of customer returns, while measuring increases or decreases relative to sales of different products, and changes in customer tastes (Jones and George, 2003, p. 334).

Fundamental to the controlling function is the monitoring roles which managers must perform. IT systems serve well in monitoring and evaluating employees' performance and recording and obtaining information about customers and products. IT has brought employee monitoring to a new height. Managers are now able to utilize information technology tools and systems to measure employee productivity, obtaining feedback and communicating ideas, resolving conflicts, and ensuring that organizational resources are being effectively and efficiently utilized to achieve targeted objectives (Mujtaba and McFarlane, 2005). Employee monitoring has become an important topic in management due to the vast uses of IT systems and tools, and the ethical implications and factors which have emerged in the forms and types of monitoring being carried out by managers via business networks. According to Mujtaba (2003), employee monitoring has emerged as a necessity and yet as a very controversial issue due to the complexity and widespread use of technology in today's workplace and business environments.

Contemporary business managers are blessed with a host of control systems and processes which can be used to measure actual performance. Through IT system applications managers are able to establish standards of performance, and compare actual performance against those standards. Such IT systems are vast in their business applications and include systems for financial measures of performance. Today's managers can readily evaluate results and take corrective actions without spending excessive time on investigating problems and finding solutions. Modern IT control systems have made it easier for managers to carry out their roles as organizational monitors and evaluators. According to Mujtaba and McFarlane (2005), the availability and variety of control systems striving with IT developments have given managers cutting edge techniques and tools which have made them more effective managers through the advantages and benefits of reduced risks and better decision making. 


\section{Leading}

Mujtaba and McFarlane (2005) state that the role of managers as leaders is instrumental to organizational success and performance, especially in the current competitive global economy where gaining a competitive edge means the difference between survival and bankruptcy. This is further emphasized by Johnson and Weinstein (2004) as they argue that companies must either strive with or "outdo" their competitors to survive and stay ahead of the game. The global economy is fueled by information and knowledge via IT tools and systems, therefore, today's managers should be effective IT leaders. They must use IT systems to communicate ideas and articulate clear visions for employees to follow, and this in turn demands the use of various medium to communicate organizational goals across the entire company, domestically and globally. This communicates the significance of IT systems becoming highly entrenched in organizational culture and management philosophy. The effective use of IT in positioning organizations for global business leadership can be accomplished in two ways: First, by managers utilizing IT to lead by empowering their workforce through the use of powerful new software programs to expand employees' knowledge, tasks and responsibilities, and secondly, by managers effectively utilizing IT in their role as leaders to organize self-managed teams or groups of employees and give them responsibility for supervising their own activities and for monitoring the quality of goods and services they produce (Jones and George 2003, p. 15).

Direct supervision has become a thing of the past as today's managers are able to use IT to lead and direct work teams while keeping focus on many critical issues. Today's managers can use self-managed teams which input results of their activities into computers, allowing middle managers to have direct access using IT systems and tools. The major benefit arising from this is the lessening of first-line managers' responsibilities and duties, as they are able to share these with workers (Parker, 1997). According to Williams (2000), the role of first-line managers in the new IT work context is to act as coaches and mentors, rather than to tell employees what to do. Their role is to provide advice and guidance and help teams find new ways to perform their tasks more efficiently.

\section{MINTZBERGIAN PERSPECTIVES ON MANAGERIAL ROLES}

The specific tasks that managers perform as they plan, organize, lead, and control organizational resources can be effectively reduced to ten roles under three broad categories. This approach to managerial roles and functions is the central management idea of Henry Mintzberg. The three broad categories of managerial roles proposed by Mintzberg are decisional, informational, and interpersonal roles. Some experts believe that IT has significantly changed how contemporary managers approach and play these roles (Williams; 2000; Griffin \& Ebert, 2004).

In their decisional roles, managers play the roles of entrepreneur, disturbance handler, resource allocator, and negotiator (Williams, 2000). Decisional roles refer to the approaches business managers utilize in planning strategy and making use of resources. IT helps a manager in the role of entrepreneur by providing more and better information to use in deciding which projects or programs to initiate, and in investing resources to increase organizational performance. In the role of disturbance handler, IT provides managers with real-time information to foresee the unexpected events or crises threatening the organization. In this way today's managers become better able to employ quick solutions. In the role of resources allocator, IT has provided managers with human resources software systems (Mujtaba and McFarlane, 2005). According to Jones and George (2003), programs such as Peoplesoft and SAP give managers easy access to the information they need to decide how to effectively utilize people and other resources to efficiently achieve organizational goals. They further argue that IT enable managers to carry out their negotiator roles as they use electronic commerce and business-to-business networks to link their organizations to suppliers, distributors and other managers, as well as their customers.

Managers act as monitors, disseminators, and spokespersons within the organization or business environment in their informational roles. As such, they utilize IT systems to obtain and transmit information across organizational boundaries, and to monitor the activities of workers and organize and control them on all levels. In their roles as disseminators, IT allows managers to quickly and effectively transmit information to all employees and other stakeholders to affect their work attitudes and behaviors (Jones and George, 2003, p. 18). IT has also allowed managers to become more effective spokespersons as they can now reach wider audiences and have more accurate information with which to influence the public and their network businesses (Mujtaba and McFarlane, 2005). 
Today's managers are figureheads, leaders and liaisons for their organizations. This is what Mintzberg uniquely describes as the Interpersonal roles of managers. IT serves to bridge the distance between managers and their organizational counterparts since they act as figureheads, leaders and liaisons. Through IT systems and tools managers become more visible throughout the organization. IT gives managers tools such as the Internet to inform employees and other interested parties such as shareholders about the organization's mission and other relevant information when they perform their figurehead roles. Using the Internet's capability through emails and other electronic communications managers can become effective role models for their employees, providing motivation and responding to their employees' needs. As organizational leaders managers need to have access to critical knowledge and information, and IT allows access to better quality information for training and counseling of subordinates. Finally, IT has enabled managers to become effective liaisons as they link and coordinate the activities of people and groups within and outside of their organizations (Jones and George, 2003 p. 19).

\section{CONCLUSION}

Information technology tools and systems provide managers with knowledge and easy access to vital information for decision making. Since the role of the manager includes "knowing who knows what, which enables the manager to leverage the knowledge of others" (Bassellier et al, 203, p. 159), having a sound IT infrastructure is relevant for business success in the information led or IT-economy of the $21^{\text {st }}$ century. Effective managers must possess tacit IT knowledge conceptualized as a combination of both experience and cognition. In today's business environment a manager's experience must include personal computing, IT projects, and overall management of IT, along with cognitive constructs or mental models and ideas in dealing with business challenges and problems (Bassellier, et al, 2001). The mental models which Bassellier and colleagues make reference to are the manager's process view and his or her vision for the role of IT. Managers in today's competitive business environment must effectively utilize IT to gain competitive advantage, increase market share, and deliver a leap in customer service (Mujtaba and McFarlane, 2005). In order to accomplish this today's managers must have enough knowledge in the use and application of IT systems and tools to address business problems and provide solutions. As such the outcomes expected from IT-competent business managers are chiefly two behaviors: an increased willingness to form partnerships with IT professionals and an increased propensity to lead and participate in IT projects (Bassellier, Reich, and Benbasat, 2001, p. 160). These collaborative partnerships and IT knowledge will further allow managers to respond to market risks and change as they venture into the new global economy.

\section{REFERENCES}

1. Allee, V. (1997). 12 Principles of Knowledge Management. Training and Development, Vol. 51, No. 11.

2. Bassellier, G., Reich \& Benbasat. (2001). Information technology competence of business managers: A definition and research model. Journal of Management Information Systems. Armonk: Spring 2001. Vol. 17, Iss. 4 ; p. 159.

3. Dilworth, J.B. (1989). Production and Operations Management: Manufacturing and Nonmanufacturing, Fourth Edition, Random House Business Division, New York.

4. Griffin, R.W., \& Ebert, R.J. (2004). Business, Seventh Edition. Pearson; Prentice-Hall, Upper Saddle River, New Jersey.

5. Holt, D.H. (1990). Management: Principles and Practices, Second Edition. Prentice-Hall, Inc. New Jersey 07632.

6. Jain, S.C. (1997). Marketing Planning \& Strategy, $5^{\text {th }}$ Edition. South-West College Publishing, Cincinnati, Ohio.

7. Johnson, W.C. \& Weinstein, A. (2004). Superior Customer Value in the New Economy: Concepts and Cases, $2^{\text {nd }}$ Edition, CRC Press, St. Lucie, Florida.

8. Jones, G.R., \& George, J.M. (2003). Contemporary Management, Third Edition. McGraw-Hill - Irwin, New York.

9. Karimi, J., Somers, T. \& Gupta, Y. (2001). Impact of Information Technology Management Practices on Customer Service. Journal of Management Information Systems. Armonk: Spring 2001. Vol. 17, Iss. 4; p. 125 . 
10. Kayworth, T., \& Leidner, D. (2002). Leadership Effectiveness in Global Virtual Teams. Journal of Management Information Systems. Armonk: Winter 2001/2002. Vol. 18, Iss. 3; p. 7

11. Laudon, K.C., and Laudon, J.P. (2004). Management Information Systems: Managing the Digital Firm, $8^{\text {th }}$ Edition. Prentice Hall, Inc. Upper Saddle River, New Jersey, NJ.

12. Laudon, K.C., and Laudon, J.P. (2004). Monitoring Employees on Networks: Unethical or Good Business? Management Information Systems: Managing the Digital Firm, $8^{\text {th }}$ Edition. Prentice Hall, Inc, p.264.

13. McEvily, S.K., Das, S., \& McCabe, K. (2000). Avoiding Competence Substitute Through Knowledge Sharing. Academy of Management Review, 25, 2, p. 294-311.

14. Mellander, K. (2001). Engaging the Human Spirit: A Knowledge Evolution Demands the Right Conditions for Learning. Journal of Intellectual Capital, 2, 2; p. 165-171.

15. Mintzberg, H. (1973). The Nature of Managerial Work, Harper and Row, New York.

16. Mujtaba, B. (2003). Ethical Implications of Employee Monitoring: What Leaders Should Consider! Journal of Applied Management and Entrepreneurship. Vol. 8, No. 3, p. 22-47; July/August.

17. Mujtaba, B., and McFarlane, D. A. (2005). Virtual Performance Management and Information Technology. Chapter in the Handbook of Globalization, Governance and Public Administration. Edited by Farazmand and Pinkowski. Marcel Dekker, Inc., NY.

18. Mujtaba, B., and McFarlane, D. A. (2005). Traditional and Virtual Performance Management Functions in the Age of Information Technology. Review of Business Information Systems, May Issue.

19. Nickels, W.G., McHugh, J.M., \& McHugh, S.M. (1999). Understanding Business, $5^{\text {th }}$ Edition. Irwin McGraw-Hill, Boston, MA.

20. Nonaka, I., \& Takeuchi, H. (1995). The Knowledge-Creating Company. Oxford University Press, Oxford, UK.

21. Oxbrow, N. (2000). Skills and Competencies to Succeed in a Knowledge Economy. Information Outlook, 4; 10, p.18-23.

22. $\quad$ Parker, S.R., Wall, T.D., \& Jackson, P.R. (1997). That's Not My Job: Developing Flexible Work Operations. Academy of Management Journal 40, p. 899-929.

23. Robbins, S.P., \& Coulter, M. (2003). Management: 2003 Update, $7^{\text {th }}$ Edition. Prentice-Hall, Inc. Upper Saddle River, New Jersey 07458.

24. Scott, J.E. (2000). Facilitating Interorganizational Learning with Information Technology. Journal of Management Information Systems. Armonk: Fall 2000. Vol. 17, Iss. 2; p. 81.

25. Thompson, Jr. A., Strickland, III, A.J., \& Gamble, J.E. (2005). Crafting and Executing Strategy: The Quest for Competitive Advantage, Concepts and Cases, $14^{\text {th }}$ Edition. McGraw-Hill/Irwin, New York.

26. Tillquist, J. (2000). Institutional Bridging: How Conceptions of IT-enabled Change Shape the Planning Process. Journal of Management Information Systems. Armonk: Fall 2000. Vol. 17, Iss. 2; p. 115

27. Turban, E., \& Aronson, J. (2003). Decision Support Systems and Intelligent Systems, $6^{\text {th }}$ Edition. PrenticeHall, Inc. New Jersey.

28. Turban, E., McClean, E., and Wetherbe, J. (1996). Information Technology for Management: Improving Quality and Productivity. John Wiley \& Sons, Inc. New York, NY.

29. Williams, A. (2000). Arthur Andersen - IT Initiatives Support Shifts in Business Strategy, Information Week, September 11, p. 14-18.

30. Williams, C. (2000). Management. South-Western College Publishing; Thomson Learning. United States.

31. Yeh, Y.M.C. (2005). Knowledge Management Implementation Model in Higher Education Industry: A Case Study in Taiwan. Proceedings of College Teaching and Learning Conference. 